\title{
Analysis of Brazilian Manufacters in the COVID-19 Diagnostic Products by ANVISA
}

\author{
Valdir Gomes Barbosa Júnior ${ }^{*}$, Roberto José da Silva Badaró1, Bruna Aparecida Souza Machado ${ }^{1}$ \\ ${ }^{1}$ University Center SENAI CIMATEC, SENAI CIMATEC, Brazil
}

\begin{abstract}
In March 2020, the World Health Organization (WHO) declared COVID-19 as a pandemic. Diagnostic and screening tests have been important tools for the clinical characterization of diseases such as COVID-19. This study aimed to analyze the presence of Brazilian manufacturers in the COVID-19 products approved by the Brazilian Health Regulatory Agency (ANVISA). This research used the ANVISA database, in which 329 registered products were identified. We classified them into 4 methods, 3 of which were the object of careful analysis. The results showed Brazil's external dependence on products from other countries, mainly from China. Keywords: COVID-19. Diagnostic Products. ANVISA.
\end{abstract}

\section{Introduction}

The year 2020 presented to the world a new scenario: the pandemic of COVID-19, a disease caused by a novel coronavirus (SARS-CoV-2). Due to the occurrence of this public health emergency on a global scale, the entire social and economic structure all over the world changed. In December 2019, Chinese government officials informed the World Health Organization (WHO) about many cases of unknown pneumonia. On March 11, 2020, WHO announced COVID-19 as a pandemic [1].

The most common symptoms of COVID-19 are dry cough, fever, and tiredness. However, some individuals present different symptoms, such as pain, runny nose, headache, conjunctivitis, sore throat, diarrhea, loss of taste or smell, rash on the skin, or discoloration of fingers or toes. It is noteworthy that about $80 \%$ of the individuals affected by the disease do not require

Received on 9 September 2020; revised 16 September 2020. Address for correspondence: Valdir Gomes Barbosa Júnior. Centro Universitário SENAI CIMATEC. Av. Orlando Gomes, 1845, Piatã. Zip Code: 41650-010. Salvador, Bahia, Brazil. E-mail: vgbjunior@gmail.com. Article selected from VI International Symposium on Innovation and Technology (SIINTEC). Section: Challenges in Science, Technology and Innovation after COVID-19.

J Bioeng. Tech. Appl. Health

C 2020 by SENAI CIMATEC. All rights reserved. hospitalization, but approximately $17 \%$ of infected patients develop a severe form of the disease, characterized mainly by shortness of breath and pneumonia. According to WHO data, the novel coronavirus pandemic is responsible for the 6th Public Health Emergency of international importance in the last 11 years: 1 . H1N1 pandemic (April 25, 2009); 2. The international spread of poliovirus (May 5, 2014); 3. Ebola outbreak in West Africa (August 8, 2014); 4. Zika virus and increased cases of microcephaly and other congenital abnormalities (February 1, 2016); 5. Ebola outbreak in the Democratic Republic of the Congo (May 18, 2018) [1].

Although Italy was the second country in the world to suffer a major pandemic-related impact, shortly after the outbreak started in China, current WHO data show that the countries with the highest number of cases, until July 30, 2020, are the United States, Brazil, India, Russia, South Africa, and Mexico. Concerning the death toll, the countries most affected are the United States, Brazil, the United Kingdom, Mexico, and Italy. In addition to the need to promote social isolation, pandemic control measures initially include the importance of carrying out mass testing of the population [2]. Although WHO indicates that testing is the main tool to contain the spread of the novel coronavirus, a restriction and difficulty of access to diagnostic products are observed worldwide, in addition to the difficulty in pacifying the strategy related to the prioritization of tests and interpretation of the results [3]. Until 
July 30, 2020, 2,610,102 cases were confirmed in Brazil, with 86,449 deaths.

On the reference date, there were $1,824,095$ people recovered and 694,744 under medical supervision. Until now, Brazil has not been able to contain the spread of the vírus [4].

Around the world, governments have adopted strict rules that restrict personal mobilities and close non-essential commerces in response to COVID-19, but such measures have been causing contractions in the economy. Some countries have managed to implement testing routines for the entire population, while others have restricted testing only to hospitalized people. The detection of SARS-CoV-2 in the population is critical to combat and control the spread of the virus. International health agencies, such as WHO, as well as scientific societies, recommend laboratory tests for patients with suspected COVID-19 as a priority in clinical management and outbreak control. As it is a new disease, diagnostic product segment industries have rapidly presented products capable of responding to emergency demand from the pandemic. Additionally, governments and regulatory agencies around the world have adopted measures to reduce the bureaucracy to the products' registration process [5]. The first step to allow the commercialization of a health product in Brazil is the registration by ANVISA, as indicated by Law 6.360/76 [6]. So, this study aimed to analyze the participation of Brazilian manufacturers in promoting access to diagnosis, from an analysis of the registries of diagnostic products for COVID-19 granted by ANVISA.

\section{Materials and Methods}

Structured research was carried out on academic research databases (Scielo; SCOPUS; PUBMED; Elsevier Researchgate; and PlosOne), and the websites of WHO and the Brazil Ministry of Health. The study was conducted in July 2020. The definitions of ANVISA and the Ministry of Health were considered to classify the products into the 4 methods extracted from the documents "Testes para COVID-19: Perguntas e Respostas" [7]; and Boletim COE COVID-19 [8]. Also, the analyses focused on rapid tests, RT-PCR, and ELISA, since these are the main types of diagnostic methods acquired by the Ministry of Health for distribution to the SUS (Unified Health System), under the program "Diagnosticar para Cuidar" [9]. The obtained data of this study occurred by the analysis of diagnosis products approved by ANVISA between May 18, 2020 (date of publication of the first specific kits registration for COVID-19) and July 31, 2020, (a link of the ANVISA website named "Fila Completa de Produtos de Diagnóstico in vitro para COVID-19") [10]. Some registries found on this link did not contain the manufacturer's information. In these cases, a detailed consult was carried out about the registration on the ANVISA website: i) consult of regularized products; ii) consult of health products; ii) consult by the number of processes. Thus, it was possible to verify the manufacturer of the registered product. However, the registration holders are mostly national distributors, which do not serve as a parameter for an analysis of the national industry presence in the market of these products. Also, the same product can be registered in Brazil by different companies, and that the proposed analyses are based on the nationality of the manufacturer in each registry.

\section{Results and Discussion}

According to ANVISA, tests related to the diagnosis of the novel coronavirus are categorized as "products for in vitro diagnostic use", which includes: "reagents, calibrators, standards, controls, sample collectors, materials and instruments used individually or in combination, with intent to use determined by the manufacturer for in vitro analysis of samples derived from the human body, exclusively or primarily to provide information for diagnostic purposes, monitoring, screening or to determine compatibility with potential blood recipients, tissues and organs" [11]. 
There are many methods to detect SARSCoV-2. The gold-standard method so far is the molecular method RT-PCR in which the genetic material (RNA) or "parts" of the genetic material (antigens) of the virus is detected. The serological test is also used, in which the antibodies against the virus (IgM and $\operatorname{IgG}$ ) are detected in the serum of patients. Among the serological tests, there are rapid tests that use the immunochromatography method, which searches for $\operatorname{IgM}$ and $\operatorname{IgG}$ antibodies against the virus. The rapid tests are performed through easy-to-use devices and are manual, capable of giving results in up to 30 minutes and without the need for support and laboratory equipment [7]. Although it could test a large number of people and quickly analysis $(<15$ minutes), this method has serious issues about low sensitivity for ill patients ( $\operatorname{IgM})$, which may lead to a misdiagnosis for COVID-19. Besides, these tests are only qualitative for the presence of $\operatorname{IgG}$ and IgM and cannot detect the onset of the disease, since the presence of these antibodies can only be detected after the seventh day of infection [12]. According to ANVISA, other serological tests requiring laboratory equipment were also registered, such as the ELISA method (EnzymeLinked Immunosorbent Assay), which is based on an enzymatic reaction, which makes the antigenantibody reaction visible by a chemical reaction, which turns visible and quantitative; as well as the CLIA method - chemiluminescent immunoassay -, in which the reading of the result is made from the fluorescence formed by the antigen reacts with the antibody, turned visible and quantitative the presence of antigen-antibody [7]. The ELISA test and CLIA are important methods, both in the clinical management of patients with suspected COVID-19 and in the control of the pandemic. These assays, unlike molecular tests, are serological tests that allow for the detection of specific antibodies (IgG and $\operatorname{IgM}$ ) produced by the immune system in the blood of infected patients or those who have already had exposure to the virus [13].

With the advent of the pandemic, and following the trend of other regulatory agencies, ANVISA published a Resolution of their Board, called RDC 348/2020, which "Defines the extraordinary and temporary criteria and procedures for the treatment of petitions for registration of medicines, biological products, and diagnostic products in vitro and postregistration change of medicines and biological products due to the international public health emergency arising from the novel Coronavirus". It is emphasized that other resolutions have also been published to facilitate the availability of other products used to combat COVID-19, such as hand sanitizers, masks, ventilators, among others [14]. Until July 30, 2020, ANVISA had published the approval of 329 applications of products for the diagnosis of COVID-19 and rejected the applications of 100 . On the same date, the agency was still expecting the Certificate of Good Manufacturing Practices of 19 companies and had placed 126 processes in demand. Among the identified registries, almost 69\% refer to rapid tests (immunochromatographic tests) (Figure 1). The total amount of this sort of test registered is higher than the total quantity of the registered tests that use other techniques. For example, the approval of ELISA tests represents 7\% and PCR, $15 \%$. Among the tests categorized as "others", there are chemiluminescent immunoassay tests (CLIA) and immunofluorescence tests.

During international health emergencies, the RT-PCR test is the gold-standard method by WHO with a high sensibility and specificity for detecting respiratory pathogens in patients with an acute respiratory infection. Soon after the emergence of the first cases of COVID-19, the presence of SARS-CoV-2 in respiratory samples was detected by RT-PCR and by partial or total sequencing of the viral genome [15]. Another issue about the product registrations at ANVISA is the difference between the quantity of national and international products. One hundred and eighty-eight registries were approved for products with Chinese manufacturers, while only 47 registries have Brazilian manufacturers (Figure 1a). As well, the number of rapid test registries were mainly from Chinese manufacturers (Figure 2b). 
Figure 1. Registries of COVID-19-tests diagnosis at ANVISA (July 30 $\left.0^{\text {th }}, 2020\right)$.

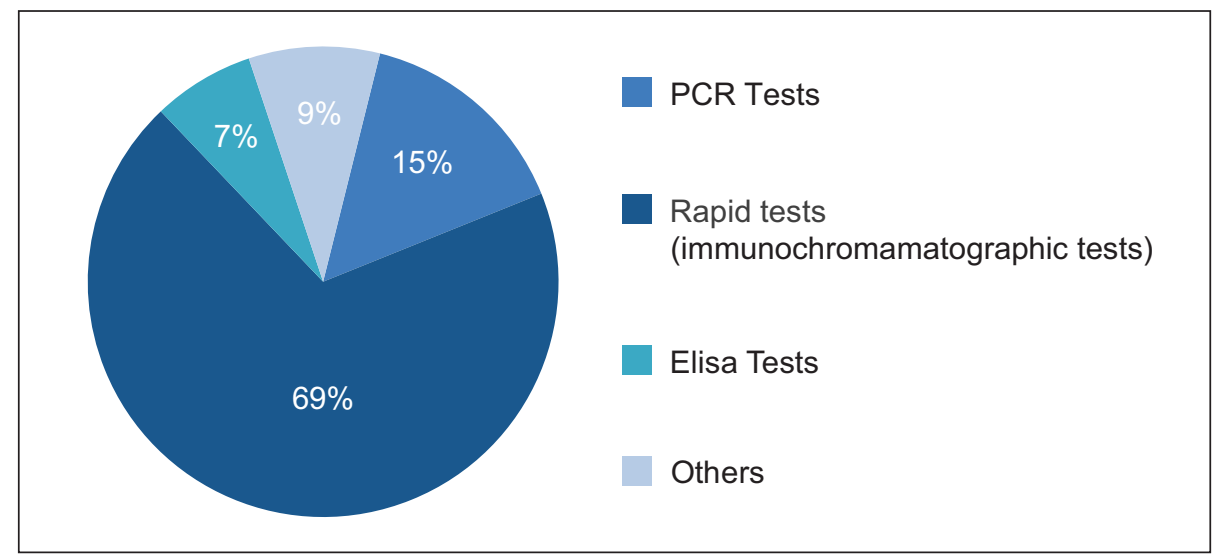

Figure 2. Total test approved by ANVISA. (a) total tests approved per country; (b) total immunochromamatographic tests (rapid tests) per country.

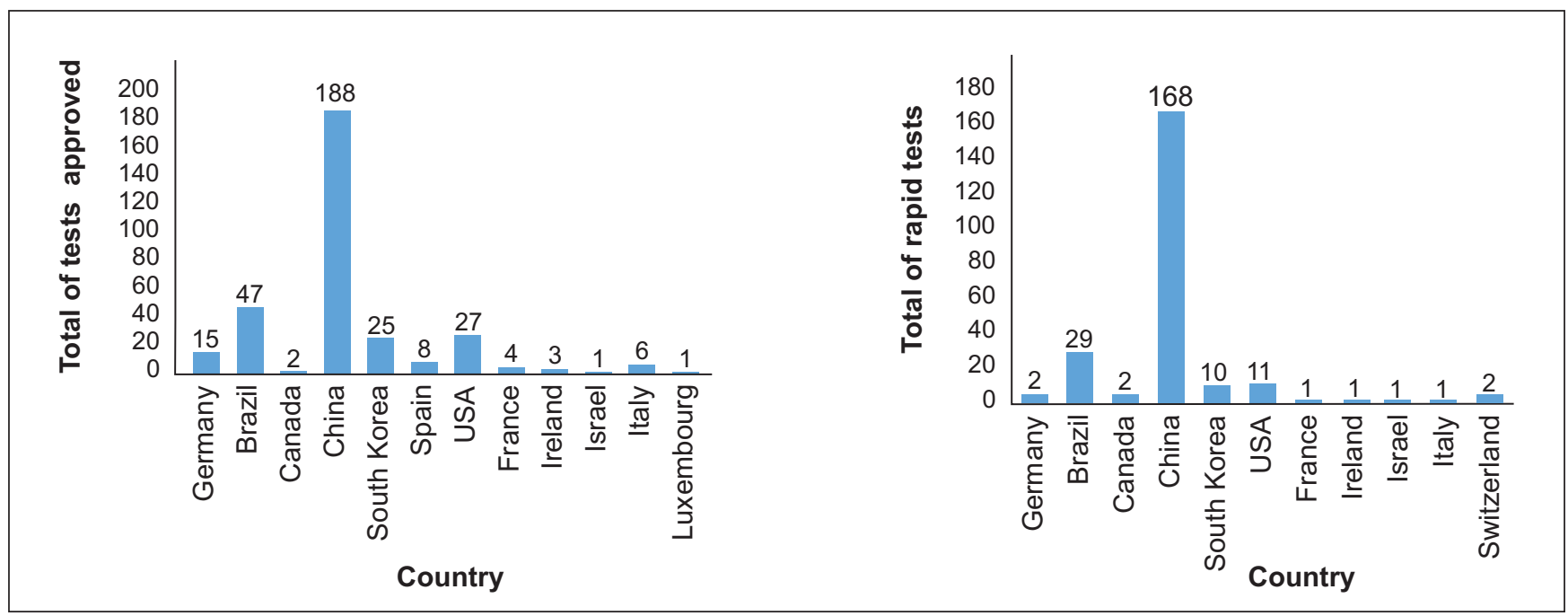

Brazil faced many difficulties in providing the necessary inputs for the operationalization of an effectivemass testing program. This fact is due to the low supply capacity of products from the Brazilian industry and the initial difficulty in acquiring inputs from the United States and China [8]. Many countries have invested in the development and distribution of new tests and their inputs and regulatory agencies have allowed additional flexibility in the registration process to promote the rapid adoption of new methods. However, despite these efforts, the overall testing capacity has not been sufficient to meet current and expected needs in some countries such as Brazil. Several factors contribute to this situation, as follow: lack of available kits or inputs for the tests; a limited number of facilities for testing; scarcity or unequal distribution of consumables and reagents for processing; insufficiency of swabs and personal protective equipment for managing the samples; and absence of certainty on how to interpret or operate the results obtained [16]. The trend repeats if we analyze the PCR method. The participation of Brazilian manufacturers is slightly higher, but still incipient when compared to 
a large number of Chinese and Korean product registries. Out of a total of 49 approved tests, 16 have Chinese manufacturers, 11 have South Korean manufacturers and only 6 have Brazilian manufacturers (Figure 3). For tests using this method, also a considerable number of products from North American manufacturers were considered as well (7 registries).

We have to highlight that the presence of products from national public laboratories between the manufacturers of Brazilian approved registries. FIOCRUZ had 4 approved products and will produce 2 PCR tests and 2 immunochromatographic tests (rapid tests). Considering Butantan Institute and Bahiafarma Foundation, the registries have also been found, but as distributors manufactured by South Korean companies. Regarding the participation of the private sector, 24 Brazilian manufacturers had products approved, which shows that there is some capacity to produce tests for diagnostics in the country. The Ministry of Health in Brazil had been distributing exclusive RT-PCR tests and rapid tests until June 2020. This action is part of the program "Diagnosticar para Cuidar", which is included in the national epidemiological and laboratory surveillance strategy for COVID-19. The program intends to perform 46 million tests this year, which would constitute approximately $22 \%$ of the Brazilian population being tested. It consists of two strands: "Confirma COVID-19", which will use the RT-PCR method (molecular biology), and "Testa Brasil", which will leverage the use of rapid tests (serology) in the country to understand the progression of the virus [9]. By the end of June 2020, the Ministry of Health announced that they would start to distribute ELISA Test as part of the program "Diagnosticar para Cuidar". This method allows the detection of antibodies with high accuracy and helps to understand the progression of the virus in the country [17]. There are 28 ELISA tests approved by ANVISA and none of them are from China. Brazilian manufacturers had 9 tests approved, while German manufactures had 9 tests approved.

Thus, Brazil is still working towards the adoption of effective methods for the diagnosis of COVID-19 that collaborate with government strategiesaimedatcontainingthepandemic.Itpoints out a gap that can still be covered by the national industry, which still has low participation in the total number of products approved by ANVISA.

\section{Conclusion}

ANVISA has worked to rapidly allow the registration of products for the diagnosis of COVID-19 in Brazil. The agency had made possible the commercialization of 2 methods listed, highlighting that the Ministry of Health has been making use of 3 of them. The number of registries containing Chinese manufacturers

Figure 3. Total RT-PCR tests approved by ANVISA per country.

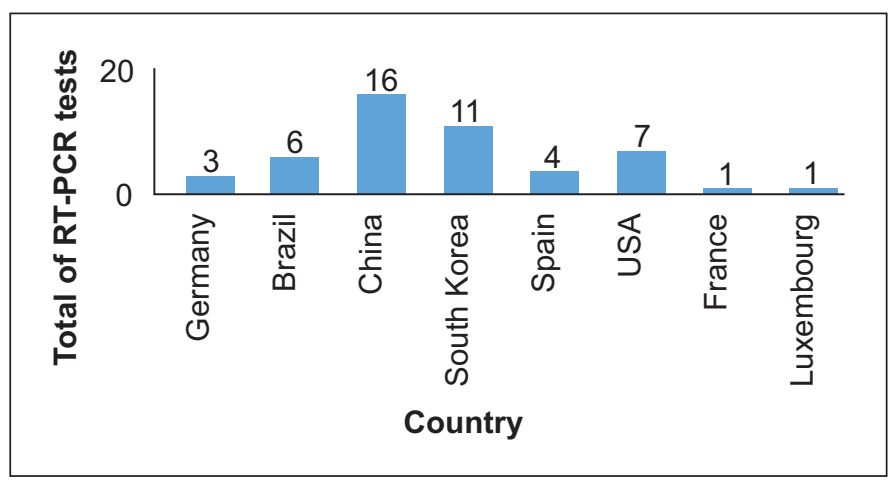


Figure 4. ELISA tests approved by ANVISA per country.

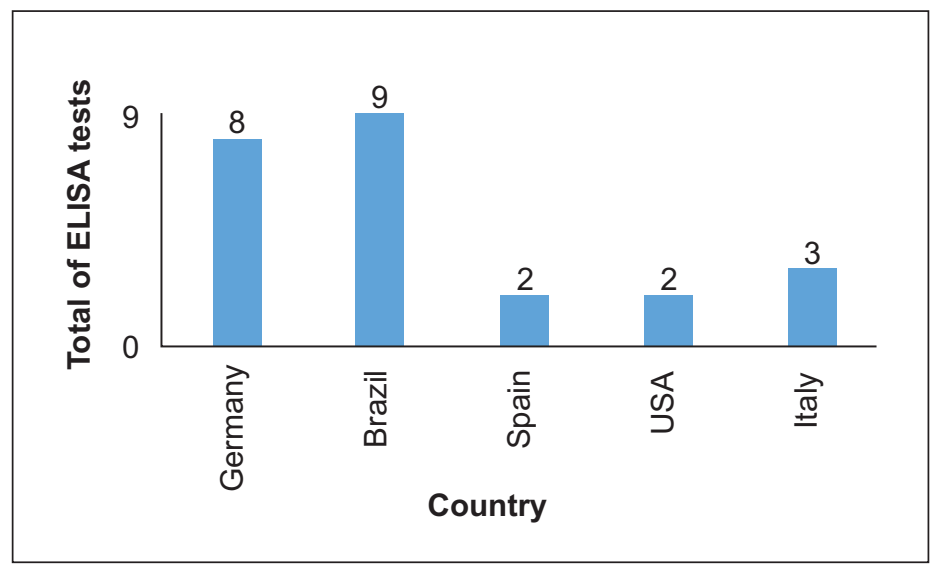

is impressive, especially regarding rapid tests (immunochromatographic), which reflects the global trend of dependence on China. Despite Brazil is the second country in the number of manufacturers, behind only China, Germany, the United States, and South Korea also have a considerable number of registrations at ANVISA.

Therefore, the analyses performed based on the participation of national manufacturers in the registries of diagnosis products of COVID-19 shows small participation of the Brazilian industry, which can be better used and stimulated by promotional mechanisms to reduce Brazil's external dependence on foreign products, especially products from China.

\section{References}

1. OPAS/OMS Brasil. OPAS/OMS Brasil - Folha informativa - COVID-19 (doença causada pelo novo coronavírus), 2020. [Online]. Available: https://www. paho.org/bra/index.php?option=com_content\&view= article $\& \mathrm{id}=6101$ : covid $19 \&$ Itemid $=8 \overline{7} 5 \#$ recomendaco es. [Accessed: 25-Jul-2020].

2. WHO. WHO Coronavirus Disease (COVID-19) Dashboard, 2020. [Online]. Available: https://covid19. who.int/table. [Accessed: 30-Jul-2020].

3. Beeching NJ, Fletcher TE, Beadsworth MBJ. COVID-19: Testing times. BMJ 2020;369(April): 1-2.

4. Brasl. Ministério da Saúde, "Covid-19 no Brasil," 2020. [Online]. Available: https://susanalitico.saude. gov.br/extensions/covid-19_html/covid-19_html.html. [Accessed: 30-Jul-2020].
5. PetherickA. Developing antibody tests forSARS-CoV-2. Lancet (London, England) 2020;395(10230):11011102.

6. Brasil. Lei 6.360, de 23 de Setembro de 1976. Dispõe sobre a Vigilância Sanitária a que ficam sujeitos os Medicamentos, as Drogas, os Insumos Farmacêuticos e Correlatos, Cosméticos, Saneantes e Outros Produtos, e dá outras Providências. [Online]. Available: http:// www.planalto.gov.br/ccivi 1_03/LEIS/L6360.htm\#art1. [Accessed: 30-Jul-2020].

7. Brasil. Agência Nacional de Vigilância Sanitária. Testes para Covid-19: perguntas e respostas. ANVISA 2020: 1-17.

8. Coe SP. Doença pelo Coronavírus 2019. Especial Vigilância Epidemiológica Laboratorial. Ministério da Saúde 2020;(12):71.

9. Brasil. Ministério da Saúde. Programa Diagnosticar para Cuidar prevê ações de testagem em 2020. [Online]. Available: https://www .saude.gov.br/noticias/agenciasaude/46848-programa-diagnosticar-para-cuidarpreve-acoes-de-testagem-em-2020. [Accessed: 30-Jul2020].

10. Brasil. Agência Nacional de Vigilância Sanitária (ANVISA). Fila Completa de Produtos de Diagnóstico in vitro para COVID-19 2020. [Online]. Available: https://app.powerbi.com/w?r=eyJrIjoiNTY5NGJmZW QtMWU3YS00ZTNjLTllZWUtNmF1ZWUyODFkYT Q5IiwidCI6ImI2N2FmMjNmLWMzZjMtNGQzNS0 4MGM3LWI3MDg1ZjVIZGQ4MSJ9. [Accessed: 31Jul-2020].

11. Brasil. Agência Nacional de Vigilância Sanitária (ANVISA). Resolução - RDC No 36, de 26 de Agosto de 2015. Dispõe sobre a classificação de risco, os regimes de controle de notificação, cadastro e registro e os requisitos de rotulagem e instruções de uso de produtos para diagnóstico in vitro, inclusive seus 
instrumentos e dá outras providências. 2015. [Online]. Available: https://www.in.gov.br/materia/-/asset publishe r/Kujrw 0TZC2Mb/ content/id/ 32 421597/ o1-2015-08-27-resolucao-rdc-n-36-de-26-de-agostode-2015-32421440. [Accessed: 30-Jul-2020].

12. Cassaniti I et al. Performance of VivaDiag COVID-19 IgM/IgG Rapid Test is inadequate for diagnosis of COVID-19 in acute patients referring to emergency room department. J Med Virol 2020.

13. Aydin S. A short history, principles, and types of ELISA, and our laboratory experience with peptide/ protein analyses using ELISA. Peptides 2015;72:4-15.

14. Brasil. Agência Nacional de Vigilância Sanitária (ANVISA). Regulamentos - ANVISA. Regulamentos,
2020. [Online]. Available: http://portal.anvisa.gov.br/ coronavirus/regulamentos. [Accessed: 30-Jul-2020].

15. Ahn DG et al. Current status of epidemiology, diagnosis, therapeutics, and vaccines for novel coronavirus disease 2019 (COVID-19). J Microbiol Biotechnol 2020;30(3):313-324.

16. Pettit SD et al. All In': A pragmatic framework for COVID-19 testing and action on a global scale. EMBO Mol Med 2020;12(6):1-8.

17. Brasil. Ministério da Saúde. Saúde passa a testar casos leves de Covid-19. [Online]. Available: https:// www.saude.gov.br/noticias/agencia-saude/47113saude-passa-a-testar-100-dos-casos-leves-de-covid-19. [Accessed: 30-Jul-2020]. 